Forthcoming: Journal of Applied Behavioral Science

The Origins of Lewin's Three Step Model of Change

\title{
Bernard Burnes
}

Chair of Organisational Change

Stirling Management School

University of Stirling

Stirling

FK9 4LA

Scotland, UK

Telephone: +44 (0)1786 467366

E-mail: bernard.burnes@stir.ac.uk 


\title{
The Origins of Kurt Lewin's Three Step Model of Change
}

\begin{abstract}
At the time of his death in 1947, Kurt Lewin was seen as one of the foremost psychologists of his day. He is now best known for his Three Step Model of Change. However, this has been criticised for its 'simplicity' and it has even been suggested that Lewin 'never developed such a model', yet this ignores its links to the rest of Lewin's work. Surprisingly, there appears to have been no rigorous attempt to understand the connection between Lewin's early work on field theory and his later work on social and organisational change. In addressing this gap in the Lewin literature, this article will show not only that the Three Step Model of Change is far from being simplistic, but also that it was a well-thought-out approach to change based on his development of field theory. The main difference between the two is one of nomenclature rather than substance.
\end{abstract}

Keywords:

Acknowledgements:
Kurt Lewin, Three Step Model, Field Theory, Group Dynamics, Action Research.

I am very grateful to Professor David Bargal and Professor Bill Cooke for their help and encouragement in the writing of this paper. 


\section{The Origins of Kurt Lewin's Three Step Model of Change}

\section{Introduction}

In his first Human Relations article, in the section headed 'Changing as Three Steps:

Unfreezing, Moving, and Freezing' (Lewin, 1947a: 34), Lewin summarises his approach to behavioural change as follows:

A successful change includes therefore three aspects: unfreezing (if necessary) the present level $L^{1}$, moving to the new level $L^{2}$, and freezing group life on the new level. Since any level is determined by a force field, permanency implies that the new force field is made relatively secure against change. (Lewin, 1947a: 35)

Since then, this has been referred to as Lewin's Three Step Model, and it has become the best-known and, arguably, the most influential approach to organisational change (Bartunek and Woodman, 2015; Burnes, 2004; Cummings and Huse, 1989; Elrod and Tippett, 2002; French and Bell, 1995; Gallos, 2006; Hendry, 1995). However, Lewin developed it as a means of resolving social conflict, such as racism, rather than primarily an approach to organisational change; and the underlying basis of the Model, field theory, which he also referred to as topological psychology, was developed by Lewin in the 1920s to investigate child behaviour (Burnes, 2017a \& b; Lewin, 1936a, 1943a, b, c \& d; Lippitt, 1947; Marrow, 1969).

As well as praise, the Three Step Model has attracted considerable criticism, not least that it is simplistic, linear, prescriptive, does not comprise a naturally occurring sequence and lacks a cognitive dimension (Bartunek and Woodman, 2015; Kanter et al, 1992; Palmer and Dunford, 1996; Weick and Quinn, 1999). Perhaps the most serious criticism is that Lewin 'never developed such a model and it took form after his death' (Cummings et al, 2016: 33). If this latter claim is correct, we would need to re-write the last 60 years or so of the change literature and it would seriously undermine the foundations on which the organization development (OD) movement is built. 
The key issue is this: does the unfreezing, moving, freezing Model presented in the Human Relations articles represent new and embryonic thinking on Lewin's part or a relabelling of his existing perspective on change? The objective of this paper is to show that the latter view is correct and that Lewin's Model represents a well-developed approach to changing human behaviour based on over 25 years of his research. In addressing this objective, five fundamental points of facts need to be recognised, as follows.

1. Though considered the 'intellectual father' of organisational change (Schein, 1988: 239), for most of his professional life Lewin was best known as a renowned child psychologist and the creator of field theory (Cartwright, 1952a \& b; Lewin, 1935 \& 1936a; Lippitt, 1947; Marrow, 1969; Wheeler, 2008).

2. Lewin considered his field theory as a metatheory, i.e. a theory from which other theories and methods can be drawn (Ash, 1992; Bargal, 2006; Lewin, 1942a; Overton and Müller, 2012). Thus it is the basis on which all his other work is built, especially the Three Step Model (Adelman, 1993; Bargal, 1998 \& 2006; Deutsch, 1968). This is why Allport (1948: ix) observes that 'All his [Lewin's] concepts ... comprise a single well-integrated system'.

3. Many see Lewin's interest in social and organisational change as only beginning, at the earliest, in 1939 and representing a break with his past work (Bartunek and Woodman, 2015; Cummings et al, 2016, Highhouse, 2002). Yet, his intent to use field theory and action research to bring about change can be traced back to the early 1930s. These are based on research originating in the 1920s (Bargal, 1998; Marrow, 1969). As Lippitt (1947: 90) observed:

The earlier studies from Berlin, and those from Cornell and the University of lowa, demonstrate the wide range of problems and situations which Kurt Lewin felt could be fruitfully analyzed with the same basic set of descriptive tools and explanatory concepts [i.e. field theory]. 
4. To appreciate why Lewin, a German Jew, became a social activist, we need to understand that he left Germany for America in 1933 as the position of Jews grew increasingly untenable (Marrow, 1969). Lewin admired much about America but was appalled by the general acceptance of racism and anti-Semitism, even in academia, and the growth of Nazism (Allport, 1948; Bernstein, 2013; Geary, 2003; Lewin, GW, 1948b; Marrow, 1969; Sokal, 1984). As Benne (1976: 28) notes:

[Lewin] found strong currents of anti-Semitism, of racism, of ethnocentrism in his adopted country ... He feared that the seeds of "totalism" might grow to destroy democracy in the United States and in the world unless the forces of research, education, and action could be united in eliminating social injustice.

So Lewin sought to apply his research to resolving social conflict, not just studying it (Burnes, 2004; Cherry \& Deaux, 2004; Cooke, 1999; Lewin, 1943d; Marrow, 1969). As his wife observes:

Kurt Lewin was so constantly and predominantly preoccupied with the task of advancing the conceptual representation of the social-psychological world, and at the same time was so filled with the urgent desire to make use of his theoretical insights for the building of a better world, that it is difficult to decide which of these two sources of motivation flowed with greater energy or vigor (Lewin, GW, 1948b: xv).

5. Though Lewin only uses the labels unfreezing, moving, and freezing in three of his final publications, the origins of his Three Step Model can be found in his application of field theory to studying child psychology in the 1920s (see Lewin, 1935, 1936a, $1941 \& 1946 b)$. His research focused on how children progressed from one developmental stage to another and, particularly, the issue of regression:

In psychology the term regression refers to a primitivation of behavior, a "going back" to a less mature state which the individual has already outgrown. (Lewin, 1941: 87)

Lewin used field theory to identify the forces driving and restraining child development, an approach he later applied to social and organisational change (Lewin, 1936a; Marrow, 1969). Therefore, even before shifting his focus to social change, Lewin was already seeing behavioural change as a process involving 
moving from one stage or level of behaviour to another (Lewin, 1936a) and recognising, as he later stated in the first of his Human Relations articles, that:

A change towards a higher level of group performance is frequently short lived; after a "shot in the arm", group life soon returns to its previous level. This indicates that it does not suffice to define the objective of a planned change in group performance as the reaching of a different level. Permanency of the new level, or permanency for a desired period, should be included in the objective. (Lewin, 1947a: 34-5).

Consequently, in examining the origins of the Three Step Model, the remainder of this paper will:

- Show that the origins of the Model lie in Lewin's work on field theory and child psychology.

- Review the two Human Relations articles in which Lewin (1947a \& b) provides a comprehensive discussion of the Model and show that the labels unfreezing, moving and freezing represented a change of nomenclature rather than a new approach to change.

- Discuss the reason for the change of nomenclature.

- Examine Lewin's Three Step Model and show its relationship to his other work and its continuing relevance.

- Conclude by arguing that the Three Step Model is a well-developed approach to change that Lewin built up over decades, and which did not represent a new departure for Lewin.

\section{Field Theory and the Origins of the Three Step Model}

Field theory is Lewin's metatheory; it provides the foundation on which all his work is built, including his Three Step Model (Adelman, 1993; Allport, 1948; Ash, 1992; Bargal, 1998 \& 2006; Cartwright, 1952b; Deutsch, 1968; Lewin, 1942a \& 1943a; Overton \& Müller, 2012). French and Bell (1973: 26), in the first OD textbook, claimed it as the 'taproot' from which OD grew. Lewin began developing field theory in 1921 (Wheeler, 2008), and in 1926 he 
published the first of a 'series of some 20 brilliant articles by himself and his students' based on and explaining field theory (Tolman, 1948: 1).

In 1936a, he published his most detailed description of field theory: Principles of Topological Psychology (Lewin, 1936a). In Chapter 1, Lewin (1936a: 6) states:

The concepts which are discussed in the following chapters have been developed and tried out in the course of the last ten years. They are based on both experimental investigations and case histories. In presenting them we are not promulgating a new "system" limited to a specific content, but rather we are describing a "tool," a set of concepts by means of which one can represent psychological reality.

Field theory sees behaviour as deriving from the totality of forces that impinge on a person or group and make up the 'life space ${ }^{1 '}$ in which the behaviour takes place (Lewin, 1942a). Lewin was greatly influenced by Gestalt psychology (Köhler 1967). A gestalt is a perceptual pattern that is the construct of the individual mind. It is a coherent whole that has specific properties that can neither be derived from individual elements nor be considered merely as the sum of them (French and Bell, 1990; Kadar and Shaw, 2000). This is why Lewin (1942a: 63) maintains that:

What is important in field theory is the way the analysis proceeds. Instead of picking out one or another isolated elements within a situation, the importance of which cannot be judged without consideration of the situation as whole, field theory finds it advantageous, as a rule, to start with a characterization of the situation as a whole.

Thus, field theory provides a means of constructing the life space which determines a person or group's behaviour, i.e. their current quasi-stationary equilibrium (Lewin, 1936a; 1943a \& 1946b). This is encapsulated in the following formula: ' $B=f(P, E)$ ', where current behaviour $B$ is a function of the interaction between $P$ (the person or group) and $E$ (their environment) $E$, i.e. $(P, E)$ is their life space and comprises 'the totality of facts which determine the behavior of an individual at a certain moment' (Lewin, 1936a: 12). So, before change can

\footnotetext{
1 As Burnes and Cooke (2013: 409) note, Lewin and his colleagues referred to the constellation of forces that shape the behaviour of a group or individual by a range of terms, including psychological environment, perceptual environment, psychological field, social field and force field. However, the most commonly used term was 'life space'. We follow this convention.
} 
begin, it is necessary to map the life space (Back, 1992; Diamond, 1992; Lewin, 1946b; Lewin and Lorsch, 1939). Only then can the quasi-stationary equilibrium, the forces maintaining the current behaviour, be destabilised and locomotion begin (Deutsch, 1968; Lewin, 1936a \& 1947a). For Lewin (1936a: 216), locomotion equals movement, i.e. ‘a change of position within a field' (Lewin,).

Lewin (1936a) contains many examples of life spaces. Figure 1a shows that of a schoolboy (P) who wishes become a doctor $(\mathrm{G})$. To reach $\mathrm{G}$, he has to overcome a number of barriers, such as passing the entry examination to college (ce).

\section{Insert Figure 1a here \\ Insert Figure 1b here}

Figure 1a merely shows the barriers that lie between P and G; it does not show all the forces in the life space. Figure $1 \mathrm{~b}$ is a fuller depiction of the schoolboy's life space. It shows forces 1 and 3 that are directly pushing the schoolboy to become a doctor, which could be pressure from family and teachers. It also shows forces that lie between the schoolboy and his goal, which could include factors such as poor exam performance. In addition, there are many indirect forces which could become barriers in the future if other forces grow or diminish in strength.

In order to achieve his goal, the schoolboy has to increase or decrease selected forces in his life space (Lewin, 1936a). However, all figure 1b shows is the schoolboy's quasi-stationary equilibrium; it does not indicate which forces to change or how to change them. Importantly, because a life space is a system, a Gestalt, a change to one force can have unintended consequences if one does not understand how that change will affect other forces in the life space (Lewin, 1936a \& 1942a). Therefore, the process of constructing a life space is not a linear one, 'but it is a procedure of "gradual approximation."' (Lewin, 1936a: 17). 
As an example of this, Lewin (1940b) describes a case of marital conflict that both partners wished to resolve. However, they had an imperfect understanding of the forces in their joint life space and what would happen once they started to change them. Thus, the actions designed to bring them closer actually drove them further apart, which required them to revisit and clarify their situation. This is why Lewin (1946a) considered change as a process of iteration and clarification.

Figure $1 b$ shows the life space before any change takes place. As Lewin (1943a \&b) explains in detail, in such situations, behaviour is relatively stable or frozen because the driving and restraining forces are in balance. 'To bring about any change, the balance between the forces which maintain the social self-regulation at a given level have to be upset', i.e. unfreezing has to occur (Lewin (1943d: 47). Therefore, the key change issue at this point is how to unfreeze, 'upset' the forces that are maintaining the quasi-stationary equilibrium.

Figure 2a shows the first step in the change process - the life space has been upset (unfrozen) to create the conditions necessary for the schoolboy to begin moving towards his goal; forces 1 and 3 have been increased and forces 4, 5, 6, 8 and 9 have been weakened. For example, if force 4 represents the schoolboy's difficulty with a particular academic subject, then additional tuition could be provided to reduce this force. Lewin's (1936a: 14) states that 'Each change of the psychological situation of a person means just this - certain events are now "possible" (or "impossible") which were previously "impossible" (or “possible")'. In essence, a degree of 'fluidity' has been created, and desired changes can take place. For Lewin (1936a: 160), 'The degree of fluidity of a situation plays an important role in all processes and is one of the fundamental dynamic properties of a situation', i.e. the more a situation is fluid (unfrozen), the easier it is to bring about change. 


\title{
Insert Figure 2a here
}

Figure $\mathbf{2 b}$ shows the schoolboy is moving towards his goal. As Lewin (1936a:48) observes:

\begin{abstract}
When he passes his college entrance examinations he has made a "step forward" on the way to his goal. ... it is real locomotion ... The examinations have brought him a step closer to his goal. The reality of the change in his position becomes clear when one considers that many things are now within his reach which were not before. He can go to college or university, his time is much more within his own control than before.
\end{abstract}

\section{Insert Figure 2b here}

Figure $2 \mathrm{c}$ shows the situation after the schoolboy has achieved his goal of becoming a doctor. It is a very different life space from figure 1b. Many of the original forces pressing for change have disappeared and been replaced by other forces. Similarly, many of the restraining forces have disappeared. In this new life space, the forces driving change may be personal ambition; the new forces resisting change might be a wish to spend time with his family. Thus a new quasi-stationary equilibrium has emerged from the change process (Lewin, 1943a \& b).

\section{Insert Figure 2c here}

However, for the change to be successful, the new quasi-stationary equilibrium has to be safe from regression (Back, 1992; Diamond, 1992; Lewin, 1944a \& 1946b). Lewin's concern with regression stems from his work as child psychologist. For Lewin (1942a), child and adolescent development is the natural order of events. It is expected that children will change, growing physically and mentally (Crowley, 2017). Throughout his career, Lewin sought to understand why some children advance to a particular developmental stage and then regress to an earlier stage of development (Brown, 1929; Lewin, 1935, 1936a, 1941; $1943 d$ \& 1946b). This is why, when considering social change, Lewin (1943d: 47-8) argues that: 
Hand in hand with the destruction of the forces maintaining the old equilibrium must go the establishment (or liberation) of forces towards a new equilibrium. Not only is it essential to create the fluidity necessary for change and to effect the change itself; it is also imperative that steps be taken to bring about the permanence of the new situation through self-regulation on the new level.

As we can see, both life space 1 (figure 1b) and life space 4 (figure $2 \mathrm{c}$ ) are examples of Lewin's quasi-stationary equilibria. In studying child development, Lewin was seeking to understand how change took place and why it sometimes failed. However, after his move to America, he became increasingly 'filled with the urgent desire to make use of his theoretical insights for the building of a better world' (Lewin, GW, 1948b: xv). To achieve this required Lewin to go beyond studying the process of locomotion to developing methods for deliberately initiating it (Lewin, 1946a; Marrow, 1969). This is where action research and group dynamics come into the picture, hence the title and subtitles of the Human Relations articles.

Action research: Lewin's interest in promoting social change can be seen in his 1934 proposal to create an action-research orientated department of psychology at the Hebrew University of Jerusalem (Adelman, 1993; Bargal, 1998). His move to America marks the start of a wide-ranging programme of action research initiatives, which began with children's clubs, but went on to include housewives, intergroup and community relations, such as religious and racial intolerance, conflict in industry, eating habits and leadership training (Burnes, 2007; Lewin, 1944b \& 1947a; Lippitt, 1947; Marrow, 1969). With the growing awareness of this work:
Many students who joined Lewin, at least after 1938, came with a practical interest in the social uses of psychological research. They found that in an era when life problems rarely received consideration from psychologists, and then only when they had reached the stage of abnormality and malfunction, Lewin's thinking was strongly life-connected. His theories were tools to attack everyday human problems. They led Lewin, in chicken- and-egg fashion, to place increasing emphasis on experimental studies of the how and what for of individual and social change - studies which later were consummated as "action research" and "group dynamics". (Marrow, 1969: 87)

Action research was developed simultaneously, but separately, by Lewin and John Collier (Bryant, 1979; Cooke, 2006; Cooke and Wolfram Cox, 2005; French and Bell, 1973). 
Lewin's (1946a) variant comprises a democratic-participative, iterative process where research (fact finding and evaluation) leads to action, and action leads to evaluation and further fact finding, which in turn leads to further action and further iterations until the objective is achieved (Coghlan, 2011; Lewin, 1946a; McTaggart,1994). Hence Lewin's famous dictum: 'No research without action, no action without research' (Marrow, 1972: 90).

Central to Action Research is the issue of choice: the voluntary participation of all concerned on equal terms and involving democratic decision-making (Coghlan and Jacobs, 2005; Lewin, 1947c; Lewin and Grabbe, 1945; McTaggart, 1994). So influential and effective has this approach to change proved that when Oreg et al (2011) undertook a meta-analysis of 60 years of the change literature, they found that participation is one of the most effective methods for ensuring the success of change initiatives.

There has been a tendency to treat action research as a stand-alone approach to change rather than an intrinsic component of the Three Step Model (Bartunek and Woodman, 2015; Coghlan, 2011), which, as Adelman (1993) notes, was never Lewin's intention. As Lewin (1946a) makes clear, the purpose of action research is to allow those involved to understand and manage the process of locomotion, i.e. to allow them to move successfully through their life space.

Group dynamics: Lewin recognised that without a theory of group dynamics it would be difficult to understand the effects of changing forces on the behaviour of groups and their members (Cartwright and Zander, 1953; Jackson, 1956; Lewin, 1944b). Lewin was the first psychologist to study group dynamics and the importance of the group in shaping the behaviour of its members (Allport, 1948; Bargal et al, 1992; Cartwright, 1951; Kippenberger, 1998). Indeed, Lewin's (1939c: 165) definition of a 'group' is still generally accepted: 'it is not the similarity or dissimilarity of individuals that constitutes a group, but interdependence of fate.' As Kippenberger (1998) notes, Lewin was addressing two questions: 
1. What is it about the nature and characteristics of a particular group that causes it to respond (behave) as it does to the forces which impinge on it?

2. How can these forces be changed in order to elicit a more desirable form of behaviour?

In seeking to bring about social change, group dynamics became a key method for understanding how a group would react to change (Cartwright, 1951; Cartwright and Zander, 1953). Lewin also found that democratic decision-making played an important role in creating a "freezing" effect once group change had taken place (Kippenberger, 1998: 12).

As the foregoing shows, the theories and tools that underpin and operationalise the Three Step model were already established well before the publication of the two Human Relations articles. Field theory was developed in the 1920s and fully articulated in Lewin's (1936a) book Principles of Topological Psychology, and action research and group dynamics were developed and used in the 1930s. Indeed, the concept of implementing social change through three interlinked processes runs through much of his writing after his arrival in America (see Cartwright, 1952a; Gold, 1999; Lewin, GW, 1948a). However, what was different in the two Human Relations articles, as the next section will show, was the new labels that Lewin used to describe his approach to change.

\section{The Two Articles: Frontiers in Group Dynamics}

As the Editors of Human Relations stated, Lewin's death 'occurred at a time when the value and effects of his work were becoming increasingly clear in many fields' (Editors, 1947: 2). Therefore, Lewin was writing for an audience who would be familiar with his work, unlike most readers today, which is why the articles can be difficult to follow (Cartwright and Festinger, 1943; Festinge, 1949; Marrow, 1969). 
The two Human Relations articles 'obsessively occupied' Lewin for the last few months of his life (Marrow, 1948: 27). Along with a book chapter (Lewin, 1947c) written at the same time, and an earlier seminar paper (Lewin, 1946c) $)^{2}$, they form his most detailed articulation of the Three Step Model. Their joint title: Frontiers in Group Dynamics, and their respective subtitles: Concept, Method and Reality in Social Science; Social Equilibria and Social Change; and Channels of Group Life; Social Planning and Action Research, encompass the work Lewin had been undertaking since the 1920s, as discussed above. Lewin (1947a: 6) makes this clear when he states that they would focus on:

(a) Quasi-stationary social equilibria and social changes [in Lewin, 1947a].

(b) Locomotion through social channels [in Lewin, 1947b].

(c) Social feedback processes and social management [in Lewin, 1947b].

Article 1: This explicitly links his Three Step Model to field theory by stating that:

A successful change includes therefore three aspects: unfreezing (if necessary) the present level $L^{1}$, moving to the new level $L^{2}$, and freezing group life on the new level. Since any level is determined by a force field, permanency implies that the new force field is made relatively secure against change. (Lewin, 1947a: 35 )

The article is divided into four parts:

Part A. Concepts, Method, and Reality in Social Science: Here Lewin (1947a: 9) observes that an attempt to change a social phenomenon can fail unless one takes account of 'such factors as the personality of the individual members, the group structure, ideology and cultural values, and economic factors', i.e. the driving and restraining forces in a group's life space. This is why he argues that 'Social events [group behaviour] depend on the social field as whole, rather than a few select items' (Lewin, 1947a: 9-10).

Lewin shows how misjudging the forces in a life space can lead to failure, with the example of conflict in marriage: a social group consisting of two people. Lewin (1947a) illustrates this

\footnotetext{
${ }^{2}$ I am very grateful to Professor Bill Cooke who discovered this paper and drew it to my attention.
} 
with five life space diagrams showing the husband's and wife's situations before any change takes place, (figures 3a and b in Lewin, 1947a: 11). Lewin (1947a: 12) concludes that:

Obviously, husband and wife will soon be in trouble if they do not "talk things over", that is, if they do not communicate to each other the structure of their life spaces with the object of equalizing them.

This emphasises one of the main constructs of Lewin's approach to change - democratic participation; all members of the group have to be involved on an equal and open basis if change is to be effective (Burnes, 2004).

Lewin (1947a: 12) comments that 'This analysis of the history of a marriage has proceeded in a series of three steps' and in order to resolve their differences and to stabilise (freeze) their changed behaviour, they will have to go through another iteration of the three steps.

Lewin (1947a: 13) concludes this section by arguing that:

Any kind of group action or individual action, even including that of the insane, is regulated by circular causal processes of the following type: individual perception or "fact-finding" - for instance an act of accounting - is linked with individual action or group action in such a way that the content of the perception or fact-finding depends upon the way in which the situation is changed by action. The result of the fact-finding in turn influences or steers action.

This 'circular' process is of course a description of Lewin's action research (Bryant, 1979; Cooke, 2006; French and Bell, 1973; Lewin, 1944b, 1946a; Marrow, 1969).

Part B. Quasi-Stationary Equilibria in Group Life and the Problem of Social Change: This continues Lewin's discussion of field theory by exploring the concept of quasi-stationary equilibria in relation to groups, pointing out that 'Change and constancy are relative concepts; group life is never without change, merely differences in the amount and type of change exist' (Lewin, 1947a: 13). 
Lewin (1947a: 15) reinforces this point when discussing the application of his change process to cases involving racial discrimination and production issues in a factory, maintaining that:

In both cases we are dealing with a process which, like a river, continuously changes its elements even if its velocity and direction remain the same. In other words, we refer to the characteristic of quasi-stationary processes.

Part C. Examples of Quasi-Stationary Equilibrium in Different Areas of Group Life: This provides further examples of field theory and behavioural change. The first example concerns the Lewin et al (1939) autocracy-democracy leadership experiments. Lewin shows how, using field theory, the insights from these experiments involving children can be used to change the behaviour of managers and political leaders. These experiments provided one of the main foundations on which he built his participative approach to group change and, in addition, they led to the rapid rise of participative management in the 1950s and 1960s (Cartwright, 1951; Cartwright and Zander, 1953; Likert, 1967; Marrow, 1969).

The second example examines factory life:

The output of a factory as a whole or of a work-team frequently shows a relatively constant level of output through an extended period of time. It can be viewed as a quasistationary equilibrium. (Lewin, 1947a: 24)

He explains that the forces maintaining this stability include factors such as a desire for more money (driving higher output) and the strain of working harder (restraining higher output). He shows how allowing a group to make its own output decisions can lead to positive and sustained change (Burnes, 2007; Marrow, 1969). Lewin (1947a: 26) notes that such a change can be achieved 'by adding forces in the desired direction or by diminishing opposing forces' and later adds that 'as a rule, the second method will be preferable'.

Lewin's final example concerns the buying and redemption of war bonds. Once again, he uses field theory to identify the driving and restraining forces that are causing or preventing changes to the quasi-stationary equilibrium, i.e. the level of war bond transactions. 
Sections B and C draw on the field theory Lewin had been developing since the 1920 s (Lewin, 1936a, 1942a, 1944a). Lewin demonstrates how it can be used to understand and change the behaviour of adult social groups, either in the community or in the workplace. His approach comprises three elements: identifying and lessening key forces in the life space of those concerned; actions to facilitate change; and strengthening the forces in the new quasi-stationary equilibrium to sustain the changed behaviour.

Part $D$. The Creation of the Permanency of Change: The remainder of the first article is devoted to an extended discussion of the Three Step Model and examples of its application. Lewin (1947a: 32) begins by stating that:

The discussion thus far implies that a planned [deliberate] change consists of transplanting the force field corresponding to an equilibrium at the beginning level $L^{1}$ by a force field having its desired level at $\mathrm{L}^{2}$.

In discussing the difficulty of overcoming the forces resisting a movement between quasistationary equilibria, Lewin (1947a: 32$)$ remarks that:

To overcome this inner resistance an additional force seems to be required, a force sufficient to "break the habit", to "unfreeze" the custom.

Lewin (1947a;35) also discusses the issue of permanency at the new level, i.e freezing, and, in a sub-section headed 'Group Decision as Change Procedure', he argues that group decision-making should permeate all three steps of the change process, and not just the freezing step. For Lewin, this democratic-participative approach to change is a key factor in achieving freezing. Subsequent research has confirmed Lewin's findings that if those involved in and affected by change are allowed to make decisions, as a group, about what to change and how to change, they will be far more committed to it than if the change is imposed (Armenakis et al, 2000; Carpenter, 2013; Diamond, 1992; McMillan and Connor, 2005; Oreg et al, 2011; Tversky and Kahneman, 1981). 
Lewin (1947a: 36) summarises his approach to change stating that:

We have seen that a planned social change may be thought of as composed of unfreezing, change of level, and freezing on a new level.

However, he does not introduce this as a new concept or untested idea, as the examples he gives from his other studies show. Indeed, if one removes the new labels, one is left with a standard description of the application of field theory to achieving sustainable social change that proceeds through three stages:

1. Identifying and destabilising the current quasi-stationary equilibrium (i.e. the constellation of forces in the life space which supports the present behaviour).

2. Locomotion through the life space (i.e. changing behaviour).

3. Creating a new quasi-stationary equilibrium that enables the new behaviour to be safe from regression.

What is different about this article from previous ones is the clearer nomenclature of these three stages, i.e. the use of unfreezing, moving and freezing. Also, where Lewin uses life space diagrams, these are clearer than many of his past examples, and in addition there is much less use of mathematical symbols and terminology than in previous discussions of field theory (e.g. Lewin, 1936a, 1940a, 1941,1943a). The change of nomenclature will be discussed below after we have examined Lewin's second article.

Article 2: The second article is much shorter than first and does not fully address the issues promised in the first article. As the Journal Editors explain, this is because:

When Professor Lewin wrote the article which appeared in the first issue of HUMAN RELATIONS, he planned to follow it with a second. Before his untimely death he was working on the manuscript of this article. Although it was far from finished and in a very preliminary form, what he had written seemed sufficiently complete to warrant publication. (Lewin, 1947b: 143).

Nevertheless, its title and contents, particularly the aim to discuss 'the role of "action research" in bringing about social change' (Lewin, 1947b: 143) indicate the intention to 
show, amongst other things, how the moving step of his Three Step Model can be operationalised.

Part A: Social Channels: Using his work on changing food habits, Lewin discusses how to modify the forces that are promoting change and those resisting it:

The force towards buying food may be composed of a number of components, such as the buyer's own like of the food, her knowledge of family likes and dislikes, or her ideas about which foods are "essential". The opposing forces may arise from a lack of readiness to spend a certain amount of money, a dislike of lengthy or disagreeable forms of preparation, unattractive taste, lack of fitness for the occasion, etc. Food is bought if the total force toward buying becomes greater than the opposing forces. (Lewin, 1947b: 144)

Lewin (1947b) moves on to discuss other forms of intentional social change, especially where one is dealing with discrimination against minorities. Again drawing on his food habits research (see Lewin, 1942b \& 1943b), he maintains that group-based decision-making produces impressive change (Lewin, 1947b).

Part B: Feedback Problems of Social Diagnosis and Action: Here Lewin (1947b) discusses his iterative, action research approach to change:

Planned social action [intentional change] usually emerges from a more or less vague "idea". An objective appears in the cloudy form of a dream or wish, which can hardly be called a goal. To become real, to be able to steer action, something has to be developed which might be called a "plan" (p147)

It should be noted that the development of a general plan presupposes "fact-finding". (p147)

On the basis of this fact-finding the goal is usually somewhat altered... (p147)

Accepting a plan does not mean that all further steps are fixed by a final decision; only in regard to the first step should the decision be final. After the first action is carried out, the second step should not follow automatically. Instead, it should be investigated whether the effect of the first action was actually what was expected. (p148).

Lewin (1947b: 149 - fig. 3) illustrates this iterative change process figuratively with a series of feedback loops at each action step, which is a standard depiction of action research (Dicken and Watkins, 2006; Wheelan and Stivers, 1990). Lewin (1947b: 150) later makes clear that he considers social action (change) as 'a type of action-research, a comparative 
research on the conditions and effects of various forms of social action, and research leading to social action'. This echoes Lewin's (1946a) article Action Research and Minority Problems.

Lewin (1947b: 150) asserts that the iterative change process allows a 'realistic determination of the nature and position of the social goal and of the direction and the amount of locomotion [change] resulting from a given action'. The use of the term 'locomotion' is telling because this is the term Lewin (1936a) uses in field theory to describe the movement between two quasi-stationary equilibria. Consequently, it can be seen that action research, which corresponds to the 'moving' element of his Three Step Model, is also how Lewin operationalised the 'locomotion' stage of his field theory (Lewin, 1947b). Lewin's (1947b) use of action research in this way is not surprising given that he developed it to bring about social change (Adelman, 1993; Bargal, 1998; Lewin, 1944b; Lewin, 1946a; Lippitt, 1947; Marrow, 1969).

Though the second article is unfinished, it shows that Lewin saw field theory as the process of determining which forces needed unfreezing, and that action research was the process by which movement would occur. Though Lewin (1947b) does not explicitly refer to how the freezing should be achieved, he does show, with the food study examples, that democratic group decision-making has the effect of sustaining behavioural change (Burnes, 2007; Lewin, 1942b \& 1943b). Similarly, in the first article, he argues that the initiative to persuade mothers to give their children more fresh milk showed the superiority of group decisionmaking for sustaining change (Lewin, 1947a: 35). He also makes similar points regarding freezing in Lewin (1947c).

To summarise, as the subtitles of the two Human Relations articles indicate, Lewin intended to cover social equilibria and social changes, group life, social planning and action research. These are concepts that arise from his work in the 1920s and 1930s and, as such, represent 
continuity with, rather than a break from, his past work. Taken together with the earlier discussion of field theory, we can see that the two articles explore and explain the key components of his Three Step Model, which in essence is a relabelling of key elements of field theory. This continuity can also be seen in Lewin (1947c: 344), which concludes that:

The effect of group decision [to change] can probably best be understood by relating it to a theory of quasi-stationary social equilibria, to social habits and resistance to change, and to the various problems of unfreezing, changing and freezing social levels.

\section{The Issue of Nomenclature}

The Three Step Model represents the approach to change that Lewin had been developing since the early 1920 s. What is different is the nomenclature:

- Unfreezing is used to describe the process of destabilising an existing quasistationary equilibrium.

- Moving replaces locomotion.

- Freezing is used to describe the process of establishing a new quasi-stationary equilibrium free from regression.

Scientific nomenclature does change over time (McNeill et al, 2012; Root and Resnick, 2003). In Lewin's case, there are three complementary explanations for this.

1. In translating his early work, there were difficulties in finding English words for German, a point made by the translators of Lewin's (1935) book A Dynamic Theory of Personality (see Translators' Preface, vii-viii). As his proficiency with English grew, one might expect changes in terminology.

2. Differences in national culture can affect the formulation of theories, the language used and their translation (Müller, 2007; Siepmann, 2006). German psychologists were more influenced by the natural sciences than American (Sokal, 1984). Lewin saw physics as the benchmark against which all other sciences would be judged (Danziger 2000: 341). For psychology to be judged a legitimate science, Lewin 
believed it had to adopt the same mathematical approach as physics (Burnes and Cooke, 2013; Danziger, 1992 \& 2000; Deutsch 1968; Lewin, 1931, 1936a, 1939a \&b, 1942a). American psychologists, brought up in a less formal and authoritarian educational environment (Lewin, 1936b), found his mathematical approach confusing (Marrow, 1969; Sokal, 1984). Therefore, it is not surprising that Lewin amended his nomenclature to reflect this (Marrow, 1969; Sokal, 1984: 1250).

3. The most obvious reason for the change is that, as Lewin embarked on real-world change, he had to explain his approach in a language that ordinary people might understand. If academics found his terminology difficult (Marrow, 1969), what chance did the rest of the populace have? Thus terminology changed and also, as Lewin (1947a, b \& c) show his diagrams became clearer and the mathematical notation was reduced.

Therefore, though the Three Step terminology introduced new labels, it did not herald any alteration to the theories and practices that he had been developing since the 1920s.

\section{Discussion: Lewin's Three Step Model}

Figure 3, taken from a leading OD textbook, shows a conventional representation of the Three Step Model. However, Lewin never represented his Model in this manner. Instead, he used life space figures and action research diagrams, such as those in Lewin (1936a \& 1947b), to illustrate the complex, iterative and participative processes that make up his Model.

Looking at figure 3, one can understand why Lewin's Model might be criticised as simplistic, linear, prescriptive, not comprising a naturally occurring sequence and lacking a cognitive dimension (Bartunek and Woodman, 2015; Kanter et al, 1992; Palmer and Dunford, 1996; Weick and Quinn, 1999). However, given Lewin's standing as a pioneering child psychologist, the originator of field theory and someone whose importance to psychology 
was compared with that of Freud (Cartwright, 1952b; Lippitt, 1947; Marrow, 1969; Tolman, 1948), and these criticisms hardly seem plausible. Also, let us not forget that Lewin (194344: 169) was also the one who coined the phrase 'there is nothing so practical as a good theory'.

Considering the criticisms in the light of our discussion of Lewin's work, we can see that the Model:

- Is not simplistic and does not lack a cognitive dimension, but is based on a deep understanding of human psychology and behaviour built up over many years (see Gold, 1999; Lewin, 1935 \& 1936a).

- Is not linear but, as his life space diagrams and action research approach in Lewin (1947a \& b) show, is an iterative process of fact-finding, action and further factfinding.

- Is not prescriptive. Instead, 'Planned social action usually emerges from a more or less vague "idea"' (Lewin, 1947b: 147) and 'The "unfreezing" of the present level may involve quite different problems in different cases' (Lewin, 1947a: 229).

- Does comprise a naturally occurring sequence. Lewin's work over 25 years found that behavioural change tended to follow a sequence of unfreezing, moving, freezing. Elrod and Tippett (2002: 288) found substantial support for this sequence when they compared 15 well-established change models from diverse and unrelated disciples. They concluded that most aligned with Lewin's Three Step Model.

It is the conventional representation of Lewin's Model that is simplistic, as a comparison with Figure 4 shows. Figure 4 is based on our examination of Lewin's work. It illustrates the iterative nature of the three processes, the core purpose of each process and the key underlying elements of the entire Model. It also helps to refute the claim that Lewin 'never developed such a model and it took form after his death' (Cummings et al, 2016: 33). As our 
examination of Lewin's work has shown, he did develop such a Model based on work begun in the 1920s. Thus, if we examine the three steps, we can see Lewin's original intention.

\section{Insert Figure 3 here \\ Insert Figure 4 here}

Step 1: The unfreezing process. For Lewin (1936a), the stability of human behaviour was based on a quasi-stationary equilibrium of driving and restraining forces within a life space. Consequently, 'The determination of the position of the person within the life space is the first prerequisite for understanding behavior' (Lewin, 1946b: 248). These forces are usually difficult to change, as people find when they try to change their behaviour (Buchanan and Sheffield, 2017; Hawkes, 2016). Thus, Lewin (1947c) saw unfreezing as a challenging process of re-education (Lewin and Grabbe, 1945), whereby, as Benne (1976: 29) notes, 'men and women alter, replace, or transcend patterns of thinking, valuation, volition, or overt behavior'. Unfreezing allows 'the fluidity necessary for change' (Lewin, 1943d: 47-8). Lewin also believed that the learning gained better equips people for future change (Coghlan and Jacobs, 2005; Lewin, 1946a).

Step 2: The moving process. Lewin (1936a: 216) originally referred to moving as locomotion, which he defined as 'a change of position within a field' and is accomplished through action research (Lewin, 1946a \& 1947b). Moving occurs when the forces pressing for change are greater than those resisting change (Lewin, 1944a \&1946a). The outcome of the moving process is usually difficult to predict due to the complexity of the forces involved, hence the iterative, exploratory nature of action research (Benne, 1978; Lewin, 1946a; Lewin, 1947b). 
Step 3: The Freezing process. This describes the changes necessary 'to bring about the permanence of the new situation' (Lewin, 1943d: 48). Freezing seeks to stabilise behaviour at a new quasi-stationary equilibrium in order to ensure that it is relatively safe from regression. Freezing requires the new behaviour to be congruent with and reinforced by the rest of the behaviour, personality and environment of those concerned in order to prevent regression (Lewin, 1936a \& 1941; Schein, 1996). Lewin saw social change as a group activity because, unless group norms and routines are also transformed, changes to individual behaviour will not be sustained (Lewin, 1947a \& b). In organisational terms, freezing can require changes to culture, norms, policies and practices (Armenakis et al, 2000; Cummings and Huse, 1989). However, as discussed, Lewin (1947a \& b) also saw freezing as arising from the nature of the change process itself, especially the degree of participation (Burnes, 2017b; Lewin, 1942b, 1943b, 1947a \& b).

When shown as figure 3, the Three Step Model does appear simplistic, but when depicted as figure 4, it emerges as a more complex approach to changing human behaviour. In particular, it allows one to appreciate that though Lewin (1947a: 10) uses the label 'Three Step Procedure', he is actually referring to three iterative processes, as our examination of his work shows (Lewin, 1935, 1936a, 1947a, b \& c; Lewin and Grabbe, 1945). In which case, why does Lewin's Model tend to be seen in terms of figure 3?

By 1947, Lewin sat at the centre of a broad network of initiatives (Burnes, 2004; Likert, 1947; Marrow, 1969). These included projects to tackle racial and religious discrimination, and conflict at work, and organisations such the Office of Naval Research, the American Jewish Congress, the Connecticut Interracial Commission, the Topology Group and two new research centres - the Research Center for Group Dynamics (RCGD) and the Commission on Community Interrelations (CCl), as well as the emerging National Training Laboratory (NTL). Though there was an overlap of people and organisations, with Lewin's death there was parting of the ways with each group focusing on a different aspect of his legacy 
(Marrow, 1969). For example, the Topology Group took ownership of field theory; the RCGD concentrated on group dynamics; the NTL devoted itself to T-groups. Alfred Marrow, Lewin's biographer, was active in most of them and was one of the few, along with Douglas McGregor, Richard Beckhard and Herbert Shepard, who seemed to adhere to a form of Lewin's Model (Freedman, 1999; French, 1982; Marrow, 1972; Marrow et al, 1967; McGill, 1974).

Up to the late 1960s, the NTL dominated the field. However, its emancipatory ideals and focus on individuals had little impact on organisational performance, and it dramatically declined (Greiner, 1972; Highhouse, 2002; Mirvis, 1988). In its place, a more businessorientated OD came to the fore, especially that promoted by the RCGD (Burnes and Cooke, 2012; Mirvis, 1998). Its involvement with Marrow on a well-documented change programme had created the template for what later became seen as 'classic' OD (Marrow et al, 1967; Oswick, 2009; Seashore and Bowers, 1970). However, though Classic OD follows Lewin's Three Step pattern and incorporates action research, it places less stress on field theory and democratic participation (Burnes and Cooke, 2013).

There have been many attempts to elaborate Lewin's Model (Armenakis and Bedeian, 1999). The most comprehensive of these appears to be Bullock and Batten's approach (1985), which seeks to synthesise some 30 models of planned change (Cummings and Huse, 1989). However, it says little about participation and does not mention field theory. Indeed, even in OD textbooks, field theory now only appears in a diluted form, i.e. Force Field Analysis (see Cummings and Worley, 2015; French and Bell, 1999). In effect, what we now have is a watered-down version of Lewin's Model.

Classic OD is far more complex than figure 3 indicates, however, bereft of Lewin's participative and field theory, it lacks the ability to identify 'the forces maintaining the old equilibrium' and the 'steps[to] be taken to bring about the permanence of the new situation' 
(Lewin, 1943d: 47-8). Field theory has not disappeared in other areas. It has been used widely in the social sphere, especially by social psychologists in resolving inter-community conflict and promoting the greater good of society (Back, 1992; Bargal and Barr, 1992; Burnes, 2017a; Wheelan et al, 1990). Indeed, such has been the breadth of its influence that the Nobel prize-winning behavioural economist Daniel Kahneman (2013: ix) commented that 'The recognition of the huge power of situation, context, priming, and construal is common ground. We are all Lewinians now'.

What are the implications for change? Firstly, we need to change how we teach OD and train OD practitioners, so as to return to Lewin's original concept of the Three Step Model. Secondly, the Model needs to be applied as originally conceived, which may well prove timely for the issues facing organisations and society today. We live in a time where environmental sustainability has become paramount, and organisations are facing increasing pressures to work with communities and campaigning groups to resolve the conflict between People, Planet and Profit (Cowley et al, 2017; Stachowicz-Stanusch, 2017; United Nations, 2015). In effect, social and organisational change are becoming intertwined. This calls for an approach to change that is capable of identifying and resolving conflicting goals and values and is seen as honest and open by all parties (Benn et al, 2014; Ratner, 2004; Scheidel et al, 2018). Lewin's Three Step Model was developed to resolve conflict. Its participative and democratic nature, along with its ability to identify the forces preventing change and those necessary to sustain change, do make it an appropriate approach to sustainability. Though Lewin never claimed that his Model would work for all forms of change or be successful in all cases, it may well be that the time is right to re-establish Lewin's original participative, field theory-based approach to change.

\section{Conclusion: The Three Step Model in Perspective}


The objective of this paper was to show that Lewin's (1947a \& b) Three Step Model represents a well-developed approach to changing human behaviour. Lewin was considered one of the foremost psychologists of his day (Lippitt, 1947; Tolman, 1948), with Likert (1947: 132) describing him as 'a great scientist, a great teacher and a great man' and Dorwin Cartwright (1952b: vii) commenting that he had 'changed fundamentally the course of social science'. Today his work is still widely cited and lies at the core of OD (Bargal et al, 1992; Burke, 2011; Burnes, 2017a; Cummings and Worley, 2015; French, 1982; French and Bell, 1999; Lewin, M, 1992). Interest in Lewin's work did not die with him and, if anything, is greater now than at the time of his death (Burnes and Cooke, 2012 \& 2013). Certainly, the fact that the Three Step Model has been shown to align with other developmental models of behaviour change (Elrod and Tippett, 2002: 273), has enhanced its credibility.

The Three Step Model has received many criticisms (Burnes 2004), but that is the nature of academic discourse and a key driver of academic progress. However, given Lewin's reputation as 'The Practical Theorist' (Marrow, 1969), what is surprising has been the nature of some of this criticism, especially that Lewin 'never developed such a model and it took form after his death' (Cummings et al, 2016: 33). In this paper, we have sought to show that the Three Step Model was a well-developed approach to change based on work begun in the 1920s, and not some vague or underdeveloped notion.

The paper began with a discussion of Lewin's field theory, showing its relationship not only to the Three Step Model, but also to group dynamics and action research. This was followed by an examination of the two Human Relations articles in which Lewin described and explained the key components of his Three Step Model and how they related to other key aspects of his work. Though the second article was unfinished, taken together, the two show that Lewin's (1947a: 34) declaration that change involved ‘Three Steps: Unfreezing, Moving, and Freezing' represents a relabelling of key elements of his field theory rather than a break with it. Subsequently, we suggested reasons why Lewin adopted the new 
nomenclature, especially the changing nature of his audience. The following Discussion provided an overview of the Three Step Model and its relationship to field theory (see figure 4). It also examined why core elements of the Model seem to have been diluted since Lewin's death.

In summary, in this paper we argue that core elements of Lewin's Model were developed in the 1920s, especially field theory, which is the metatheory on which his work rests. In moving from the laboratory to the real world in the 1930s, Lewin was driven by 'the urgent desire to make use of his theoretical insights for the building of a better world' (Lewin, GW, 1948: xv). Which is to say, that his approach to social change was not something new, but built on his existing work. Therefore, the Three Step Model is neither a 'simple one' nor a 'never developed' one, but instead a robust approach to understanding the complexity of human behaviour and how it can be changed. 


\section{References}

Adelman, C (1993). Kurt Lewin and the Origins of Action Research. Educational Action Research, 1 (1), 7-24.

Allport, GW (1948) Foreword. In Lewin, GW (Ed.), Resolving Social Conflicts. London: Harper \& Row. pp vii-xivi.

Armenakis, AA and Bedeian, AG (1999) Organisational change: a review of theory and research in the 1990s. Journal of Management, 25 (3), 293-315.

Armenakis, AA; Harris, SG; and Field, HS (2000) Making change permanent: A model for institutionalizing change interventions. In RW Woodman, WA Pasmore and AB Shani (Eds) Research in Organizational Change and Development, Vol 12. Emerald Group Publishing: Bradford. pp 97-128.

Ash, MG (1992) Cultural contexts and scientific change in psychology - Lewin, Kurt in lowa. American Psychologist, 47(2), 198-207.

Back, KW (1992) This business of topology. Journal of Social Issues, 48, 51-66.

Bargal, D (1998). Kurt Lewin and the first attempts to establish a department of Psychology at the Hebrew University. Minerva, 36 (1), 49-68.

Bargal, D (2006) Personal and intellectual influences leading to Lewin`s paradigm of action research. Action Research, 4 (4), 367-388.

Bargal, D and Bar, H (1992) A Lewinian approach to intergroup workshops for ArabPalestinian and Jewish youth. Journal of Social Issues, 48(2), 139-54.

Bargal, D; Gold, M; and Lewin, M (1992) The heritage of Kurt Lewin - introduction. Journal of Social Issues, 48 (2), 3-13.

Bartunek, JM and Woodman, RW (2015) Beyond Lewin: Toward a Temporal Approximation of Organization Development and Change. In F. P. Morgeson, H. Aguinis, \& S. J. Ashford (Eds): Annual Review of Organizational Psychology and Organizational Behavior, Vol. 2 (pp. 157-182). Palo Alto, CA: Annual Reviews.

Benn, S, Dunphy, D and Griffiths, A (2014) Organizational Change for Corporate Sustainability ( $3^{\text {rd }}$ edition). Routledge: London.

Benne, KD (1976) The Processes of Re-Education: An Assessment of Kurt Lewin's Views. Group \& Organization Studies, 1 (1), 26-42.

Bernstein, A (2013) Swastika Nation: Fritz Kuhn and the Rise and Fall of the GermanAmerican Bund. St Martin's Press: New York, NY.

Bowers, DG and Seashore, SE. (1967a) Implications for Managing Organizational Change. In AJ Marrow, DG Bowers and SE Seashore (Eds): Management by Participation. Harper \& Row: New York, NY, pp225-245.

Brown, JF (1929) The methods of Kurt Lewin in the psychology of action and affection. Psychological Review, 36 (3), 200-221.

Bryant, D (1979) The Psychology of Resistance to Change. Management Services, March, 10-11. 
Buchanan, K and Sheffield, J (2017) Why do diets fail? An exploration of dieters' experiences using thematic analysis. Journal of Health Psychology, 22 (7) 906-915.

Bullock, RJ and Batten, D (1985) It's just a phase we're going through: a review and synthesis of OD phase analysis. Group and Organization Studies, 10 (December), 383-412.

Burke WW (2011) On the legacy of Theory Y. Journal of Management History, 17 (2), 193201.

Burnes, B (2004) Kurt Lewin and the planned approach to change: a re-appraisal. Journal of Management Studies, 41 (6), 977-1002.

Burnes, B (2007) Kurt Lewin and the Harwood studies: the foundations of OD. Journal of Applied Behavioral Science, 43 (2), 213-31.

Burnes (2017a) Kurt Lewin (1890-1947): The Practical Theorist. In DB Szabla, WA Pasmore, MA Barnes and AN Gipson (Eds): The Palgrave Handbook of Organizational Change Thinkers. Palgrave Macmillan: New York, NY. DOI https://doi.org/10.1007/978-3-319-498201_13-1.

Burnes, B (2017b) Managing Change ( $7^{\text {th }}$ Edition). Pearson: Harlow.

Burnes, B and Cooke, B (2012) The past, present and future of organization development: taking the long view. Human Relations, 65 (11), 1395-429.

Burnes, B and Cooke, B (2013) Kurt Lewin's field theory: a review and re-evaluation. International Journal of Management Reviews, 15, 408-425.

Carpenter, CJ (2013) A meta-analysis of the effectiveness of the 'but you are free' compliance-gaining technique. Communication Studies, 64(1), 6-17.

Cartwright, D (1951) Achieving change in people: some applications of group dynamics theory. Human Relations, 4 (4), 381-92.

Cartwright, D (Ed) (1952a) Field Theory in Social Science: Selected Theoretical Papers by Kurt Lewin. Social Science Paperbacks: London.

Cartwright, D. (1952b). Foreword. In Cartwright, D. (ed.), Field Theory in Social Science: Selected Theoretical Papers by Kurt Lewin. London: Social Science Paperbacks. pp. vii-xv.

Cartwright, D. and Festinger, L. (1943). A quantitative theory of decision. Psychological Review, 50, 595-621.

Cartwright, D and Zander, A (1953) Group Dynamics: Research and theory. Row, Peterson and Co: White Plains, NY.

Cherry, F and Deaux, K (2004) The Lewinian Legacy in SPSSI. Talk presented at International Conference: Kurt Lewin: Contribution to Contemporary Psychology, MogilnoBydgoszcz, Poland, September, 10-12.

Coghlan, D (2011) Action Research: Exploring Perspectives on a Philosophy of Practical Knowing. The Academy of Management Annals, 5 (1), 53-87. 
Coghlan, D and Jacobs, C (2005) Kurt Lewin on Reeducation: Foundations for Action Research. Journal of Applied Behavioral Science, 41 (4), 444-457.

Cooke, B (1999) Writing the Left out of Management Theory: The Historiography of the Management of Change. Organization, 6 (1), 81-105.

Cooke, B (2006) The Cold War Origin of Action Research as Managerialist Cooptation: Human Relations, 59 (5), 655 -693

Cooke, B and Wolfram Cox, J (Eds) (2005) Fundamental of Action Research (Vols 1-4). SAGE: London.

Crowley, K (2017) Child Development (2 ${ }^{\text {nd }}$ Edition). Sage: London.

Cummings, S; Bridgman, T; and Brown, KG (2016) Unfreezing change as three steps: Rethinking Kurt Lewin's legacy for change management. Human Relations, 69 (1) 3360.

Cummings, TG and Huse, EF (1989) Organization Development and Change (4th edition). West: St Paul, MN.

Cummings, TG and Worley, CG (2015) Organization Development and Change $\left(10^{\text {th }}\right.$ Edition). Cengage: Stamford, CT.

Danziger, K (1992) The project of an experimental social psychology: historical perspectives. Science in Context, 5 (2),309-328.

Danziger, K (2000) Making social psychology experimental: a conceptual history, 19201970. Journal of the History of the Behavioral Sciences, 36 (4), 329-347.

Deutsch, M (1968). Field theory in social psychology. In Lindzey, G and Aronson, E (Eds): The Handbook of Social Psychology, Vol. 1 (2nd Edn). Reading, MA: Addison-Wesley. Pp 412-487.

Diamond, GA (1992) Field theory and rational choice: a Lewinian approach to modelling motivation. Journal of Social Issues, 48 (2), 79-94.

Dickens, L and Watkins, K (2006) Action Research: Rethinking Lewin. In JV Gallos (ed): Organization Development: A Jossey-Bass Reader. Jossey-Bass: San Francisco, CA. pp 185-201.

Editors (1947) Editorial Policy. Human Relations, 1 (1), 1-2.

Elrod II, PD and Tippett, DD (2002) The 'death valley' of change. Journal of Organizational Change Management, 15 (3), 273-91.

Festinger, L. (1949). The analysis of sociograms using matrix algebra. Human Relations, 2 (2), 153-158.

Freedman A (1999) The history of organization development and the NTL Institute: What we have learned, forgotten and rewritten. The Psychologist-Manager Journal, 3 (2), 125-141.

French WL (1982) The emergence and early history of organization development: With reference to influences on and interaction among some of the key actors. Group \& Organization Studies, 7 (3): 261-278. 
French, WL and Bell, CH (1973) Organization Development ( $1^{\text {st }}$ Edition). Englewood Cliffs, NJ: Prentice Hall.

French, WL and Bell, CH (1995) Organization Development (5th edition). Englewood Cliffs, NJ: Prentice Hall.

French, WL and Bell, CH (1999) Organization Development (6th edition). Prentice Hall: Upper Saddle River, NJ.

Gallos, JV (Ed) (2006). Organization Development: A Jossey-Bass Reader. Jossey-Bass:

San Francisco, CA.

Gold, M (Ed) (1999) The Complete Social Scientist: A Kurt Lewin Reader. American Psychological Association: Washington, DC.

Greiner LE (1972) Red flags in organization development. Business Horizons 1972(June): 17-24.

Hawkes, N (2016) Sixty seconds on . . New Year resolutions. BMJ: British Medical Journal (Online), 355, December 30. Available at https://doi.org/10.1136/bmj.i6845.

Hendry, C (1996) Understanding and creating whole organizational change through learning theory. Human Relations, 48 (5), 621-41.

Highhouse S (2002) A history of the T-group and its early applications in management development. Group Dynamics: Theory, Research and Practice 6 (4), 277-290.

Jackson, JM (1956) Current Trends in Group Dynamics Research and Theory. Research Center for Group Dynamics, Institute for Social Research, University of Michigan: Ann Arbor, MI.

Kadar, EE and Shaw, RE (2000) Toward an ecological field theory of perceptual control of locomotion. Ecological Psychology, 12 (2), 141-180.

Kanter, RM; Stein, BA; and Jick, TD (1992) The Challenge of Organizational Change. New York: Free Press.

Kahneman, D (2013) Foreword. In E Shafir (Ed): The Behavioral Foundations of Public Policy. Princeton University Press: Princeton, NJ. (ppvii-ix)

Kippenberger, T (1998) Planned change: Kurt Lewin's legacy. The Antidote, 3 (4), 10-12.

Köhler, W (1967) Gestalt psychology. Psychological Research, 31 (1), XVIII-XXX.

Likert, R (1947) Kurt Lewin: A Pioneer in Human Relations Research. Human Relations, 1 (1), 131-139.

Lewin, GW (Ed) (1948a). Resolving Social Conflict. Harper \& Row: London.

Lewin, GW (1948b) Preface. In GW Lewin (Ed): Resolving Social Conflict. Harper \& Row: London. pp xv-xviii. 
Lewin, K (1931). The Conflict between Aristotelian and Galilean Modes of Thought in Contemporary Psychology. In M Gold (Ed) (1999): The Complete Social Scientist: A Kurt Lewin Reader. American Psychological Association: Washington, DC. pp. 37-66.

Lewin, K (1935) A Dynamic Theory of Personality: Selected Papers. McGraw-Hill: New York, NY.

Lewin, K (1936a) Principles of Topological Psychology. McGraw-Hill: New York, NY.

Lewin, K (1936b) Some Social-Psychological Differences Between The United States and Germany. In GW Lewin (ed) (1948): Resolving Social Conflict. Harper \& Row: London. pp 333.

Lewin, K (1939a) Experiments in Social Space. In GW Lewin (Ed) (1948): Resolving Social Conflict. Harper \& Row: New York, NY. pp 71-83.

Lewin, K. (1939b). Field theory and experiment in social psychology: concepts and methods. American Journal of Sociology, 44 (6), 868-896.

Lewin, K (1939c) When facing danger. In GW Lewin (ed) (1948): Resolving Social Conflict. Harper \& Row: London. pp 159-168.

Lewin, K (1940a) Formalization and Progress in Psychology. In D Cartwright, D (Ed): (1952) Field Theory in Social Science: Selected Theoretical Papers by Kurt Lewin. London: Social Science Paperbacks. pp1-29.

Lewin, K (1940b) The Background to Conflict in Marriage. In GW Lewin (Ed) (1948):

Resolving Social Conflicts. Harper \& Row: New York, N, pp 84-102.

Lewin, K (1941) Regression, Retrogression and Development. In D Cartwright (Ed): (1952) Field Theory in Social Science: Selected Theoretical Papers by Kurt Lewin. London: Social Science Paperbacks. pp 87-129.

Lewin, K. (1942a). Field theory and learning. In D Cartwright (Ed): (1952) Field Theory in Social Science: Selected Theoretical Papers by Kurt Lewin. London: Social Science Paperbacks. pp 60-86.

Lewin, K (1942b) The Relative Effectiveness of a Lecture Method and a Method of Group Decision for Changing Food Habits. Committee on Food Habits, National Research Council: Washington, DC.

Lewin, K (1943a) Defining the "Field" at a Given Time. In D Cartwright (Ed): (1952) Field Theory in Social Science: Selected Theoretical Papers by Kurt Lewin. London: Social Science Paperbacks. pp 43-59.

Lewin, K. (1943b). Forces behind food habits and methods of change. Bulletin of the National Research Council, 108, 35-65.

Lewin, K (1943c) Psychological Ecology. In D Cartwright (Ed): (1952) Field Theory in Social Science: Selected Theoretical Papers by Kurt Lewin. London: Social Science Paperbacks. pp170-187.

Lewin, K (1943d) The Special Case of Germany. In GW Lewin (Ed) (1948): Resolving Social Conflict. Harper \& Row: New York, NY. pp 43-55. 
Lewin, K (1943-44) Problems of Research in Social Psychology. In D Cartwright (Ed): (1952) Field Theory in Social Science: Selected Theoretical Papers by Kurt Lewin. London: Social Science Paperbacks. pp155-169.

Lewin, K (1944a) Constructs in Field Theory. In D Cartwright (Ed): (1952) Field Theory in Social Science: Selected Theoretical Papers by Kurt Lewin. London: Social Science Paperbacks. pp 30-42.

Lewin, K (1944b) The Dynamics of Group Action. Educational Leadership, January, 195200.

Lewin, K (1946a) Action Research and Minority Problems. In GW Lewin (Ed) (1948):

Resolving Social Conflict. Harper \& Row: New York, NY. pp 201-216.

Lewin, K. (1946b). Behaviour and Development as Function of the Total Situation. In D Cartwright: (Ed): (1952) Field Theory in Social Science: Selected Theoretical Papers by Kurt Lewin. London: Social Science Paperbacks. pp 238-305.

Lewin, K (1946c) Notes of Talk to Bureau of Intercultural Education, New York, 29 March 1946. Research Center for Group Dynamics Archive, Box 3-141, Bentley Historical Library, University of Michigan: Ann Arbor.

Lewin, K (1947a) Frontiers in Group Dynamics: Concept, Method and Reality in Social Science; Social Equilibria and Social Change. Human Relations, 1 (1), 5-41.

Lewin, K (1947b) Frontiers in Group Dynamics II: Channels of Group Life; Social Planning and Action Research. Human Relations, 1 (2), 143-153.

Lewin, K (1947c) Group Decision and Social Change. In TM Newcomb and EL Hartley (Eds): Readings in Social Psychology. New York, NY: Henry Holt. pp 330-344.

Lewin, K (1949) Cassirer's philosophy of science and the social sciences. In Gold, M (Ed) (1999) The Complete Social Scientist: A Kurt Lewin Reader. Washington, DC: American Psychological Association. 23-36.

Lewin, K and Grabbe, P (1945) Conduct, Knowledge, and Acceptance. Journal of Social Issues, 1 (3), 53-64.

Lewin, K; Lippitt, R; and White, RK (1939) Patterns of aggressive behavior in experimentally created "social climates". Journal of Social Psychology, 10 (2), 271-299.

Lewin, K and Lorsch, K (1939) Mathematical constructs in psychology and sociology. Journal of Unified Science, 8 (1), 397-403.

Lewin, M (1992) The impact of Kurt Lewin's life on the place of social issues in his work. Journal of Social Issues, 48, 2, 15-29.

Likert, R (1947) Kurt Lewin: A Pioneer in Human Relations Research. Human Relations, 1 (1), 131-139.

Likert, R (1967) The Human Organization: Its management and values. McGraw-Hill: New York.

Lippitt, R (1939) Field theory and experiment in social psychology: autocratic and democratic group atmospheres. American Journal of Sociology, 45 (10, 26-49. 
Lippitt, R (1947). Kurt Lewin, 1890-1947. Adventures in the Exploration of Interdependence. Sociometry, 10 (1), 87-97.

McGill, ME (1974) The Evolution of Organization Development: 1947-1960. Public Administration Review, 34 (2), 98-105.

McMillan, B and Connor, M (2005) Motivating personal change. In J Kerr; R Weitkunat; and M Moretti (Eds): ABC of Behavior Change. Elsevier Churchill Livingstone: Edinburgh.

McNeill, J; Turland, NJ; Barrie, FR; Buck, WR; Greuter, W and Wiersema, JH (2012) International Code of Nomenclature for Algae, Fungi, and Plants. Koeltz Scientific Books: Konigstein, Germany.

McTaggart, R (1994) Participatory Action Research: issues in theory and practice, Educational Action Research, 2 (3), 313-337.

Marrow, AJ (1948) Kurt Lewin. Journal of Social Issues, 4 (1), 27-34

Marrow, AJ (1969) The Practical Theorist: The Life and Work of Kurt Lewin. New York, NY: Teachers College Press.

Marrow, AJ (1972) The effects of participation on performance. In AJ Marrow (Ed): The Failure of Success. Amacom: New York.

Marrow, AJ; Bowers, DG and Seashore, SE (Eds) (1967) Management by Participation. New York, NY: Harper \& Row.

Mirvis, PH (1988). Organization Development: Part 1 - An Evolutionary Perspective. In WA Pasmore and RW Woodman (Eds): Research in Organizational Change and Development Vol 2. JAI Press: Greenwich, CN. (1-57)

Müller, M (2007) What's in a word? Problematizing translation between languages. Area, 39 (2), 206-213.

Oreg, S (2003) Resistance to change: developing an individual differences measure. Journal of Applied Psychology, 88 (4), 680-93.

Oreg, S; Vakola, M; and Armenakis, A (2011) Change recipients' reactions to organizational change: a 60-year review of quantitative studies. Journal of Applied Behavioral Science, 47 (4), 461-524.

Oswick C (2009) Revisioning or re-versioning?: A commentary on diagnostic and dialogic forms of organization development. Journal of Applied Behavioral Science 45 (3), 369-374.

Overton, WF and Müller, U (2012) Metatheories, theories, and concepts in the study of development. In RM Lerner; MA Easterbrooks; and J Mistry (Eds): Developmental psychology. Volume 6 of the Handbook of Psychology. Hoboken, NJ: Wiley. pp 19-58.

Palmer I and Dunford R (1996) Conflicting uses of metaphors: reconceptualizing their use in the field of organizational change. Academy of Management Review, 21, 691-717.

Ratner, BD (2004) "Sustainability" as a Dialogue of Values: Challenges to the Sociology of Development. Sociological Inquiry, 74 (1), 50-69.

Root, RW and Resnick, RJ (2003) An Update on the Diagnosis and Treatment of 
Attention-Deficit/Hyperactivity Disorder in Children. Professional Psychology: Research and Practice, 34 (1), 34-41.

Scheidel, A, Temper, L, Demaria, F and Martinez-Alier, J (2018) Ecological distribution conflicts as forces for sustainability: an overview and conceptual framework. Sustainability Science, 3, 585-598.

Schein, EH (1988) Organizational Psychology (3rd Edn). Prentice Hall: Englewood Cliffs, NJ.

Schein, EH (1996) Kurt Lewin's Change Theory in the Field and in the Classroom: Notes Toward a Model of Managed Learning. Systems Practice, 9 (1), 27-46.

Seashore, SE and Bowers, DG (1970) Durability of Organizational Change. American Psychologist, 25 (3), 227-233.

Siepmann, D. (2006). Academic Writing and Culture: An Overview of Differences between English, French and German. Meta, 51(1), 131-150.

Sokal, MM (1984) The Gestalt Psychologists in Behaviorist America. The American Historical Review, 89 (5), 1240-1263.

Stachowicz-Stanusch, A (Ed) (2017) Corporate Social Performance: Reflecting on the Past and Investing in the future. Information Age: Charlotte, NC.

Tolman, E (1948) Kurt Lewin: 1890-1947). The Psychological Review, 55 (1), 1-4.

Tversky, A and Kahneman, D (1981) The framing of decisions and the psychology of choice. Science, 211 (4481), 453-8.

United Nation's (2015b) Sustainable Development Goals: 17 Goals to Transform our World. United Nations: New York, NY. Available at http://www.un.org/sustainabledevelopment/sustainable-development-goals/

Weick KE and Quinn RE (1999) Organizational change and development. Annual Review of Psychology, 50, 361-386.

Wheelan, SA and Stivers, EH (1990) Group Dynamics, Action Research, and Intergroup Relations. In SA Wheelan; EA Pepitone; and V Abt (Eds): Advances in Field Theory. SAGE: London. pp197-209.

Wheeler, L (2008). Kurt Lewin. Social and Personality Psychology Compass, 2 (4), 16381650. 


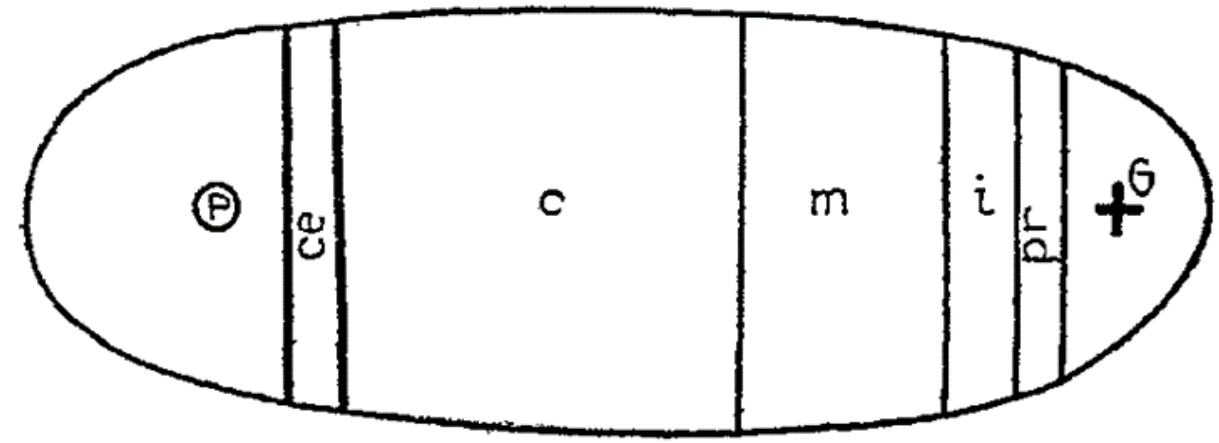

Figure 1a: A Simple Depiction of the Schoolboy's Life Space (from Lewin, 1936:48 - Figure 4)

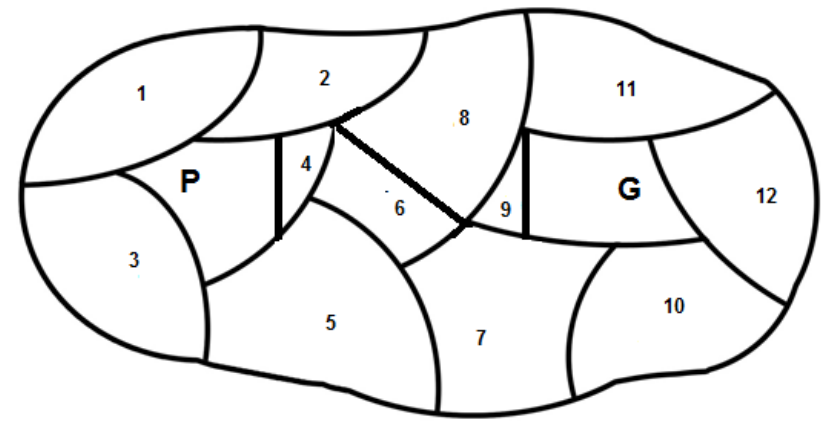

Figure 1b: A Complex Depiction of the Schoolboy's Life Space 


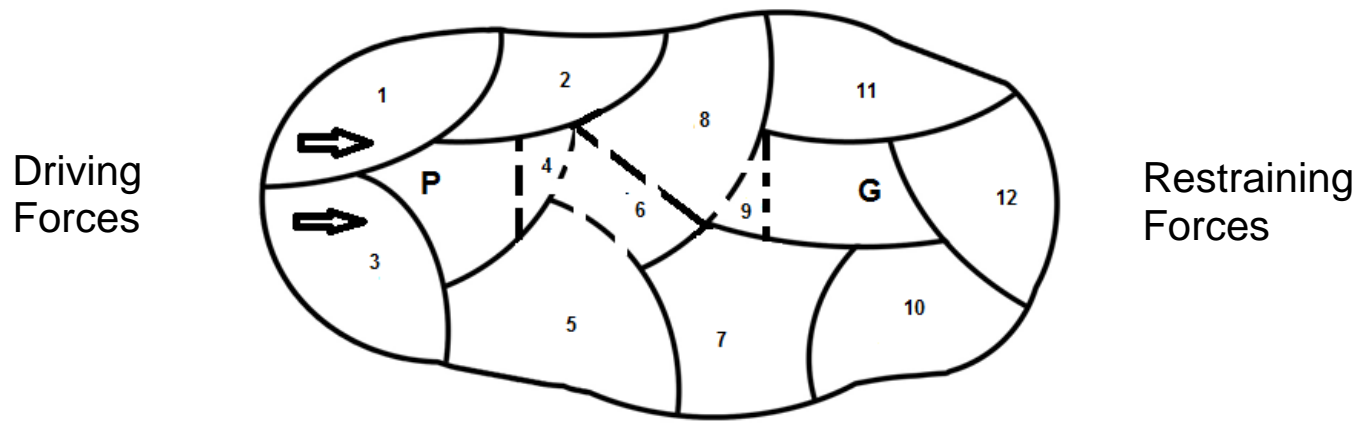

Figure 2a: Increasing and Decreasing Forces 
Driving

Forces

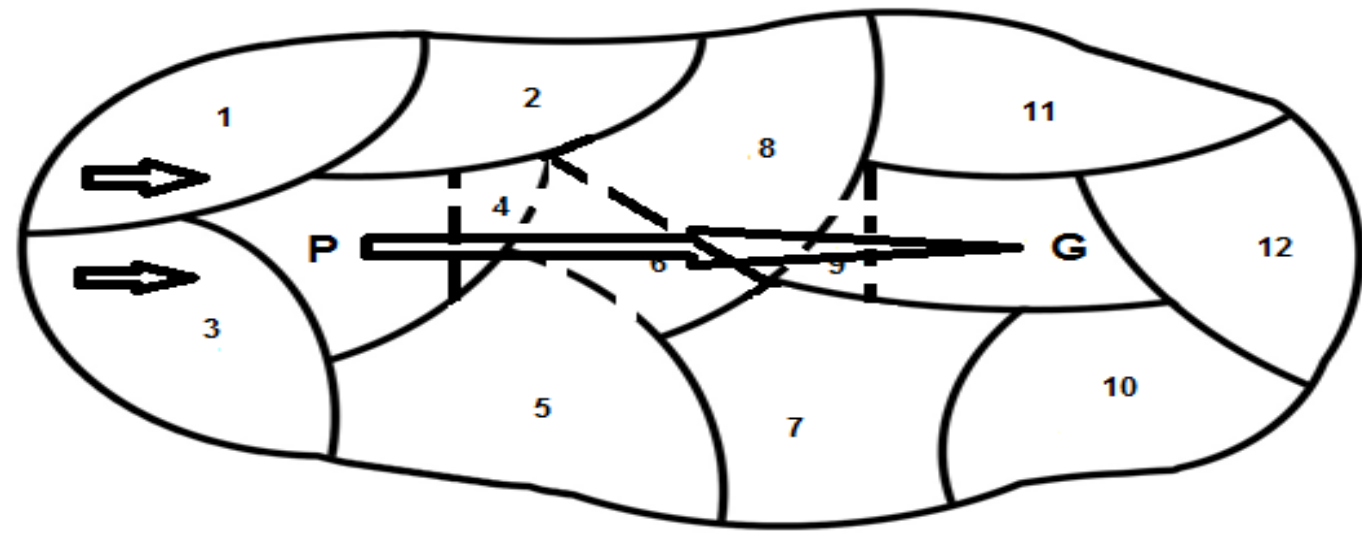

Restraining Forces

Figure 2b: Locomotion: Moving Towards the Goal. 


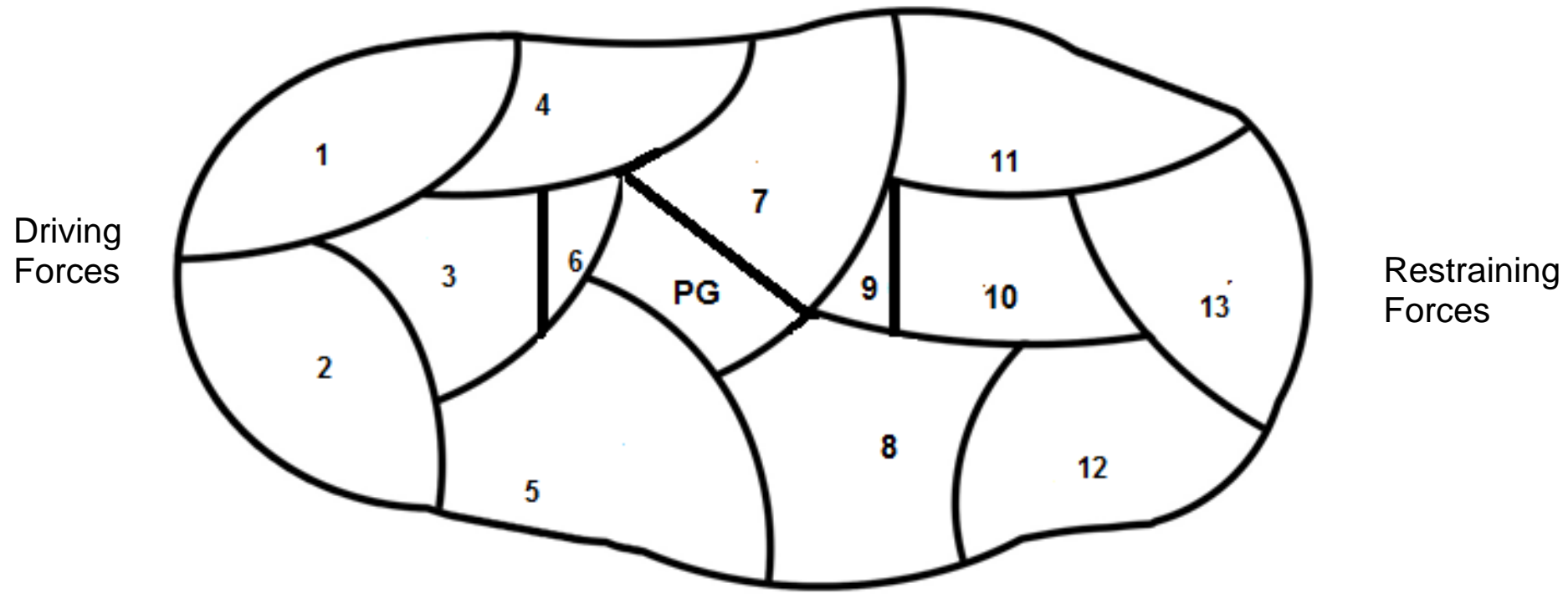

Figure 2c: The Life Space After the Change 


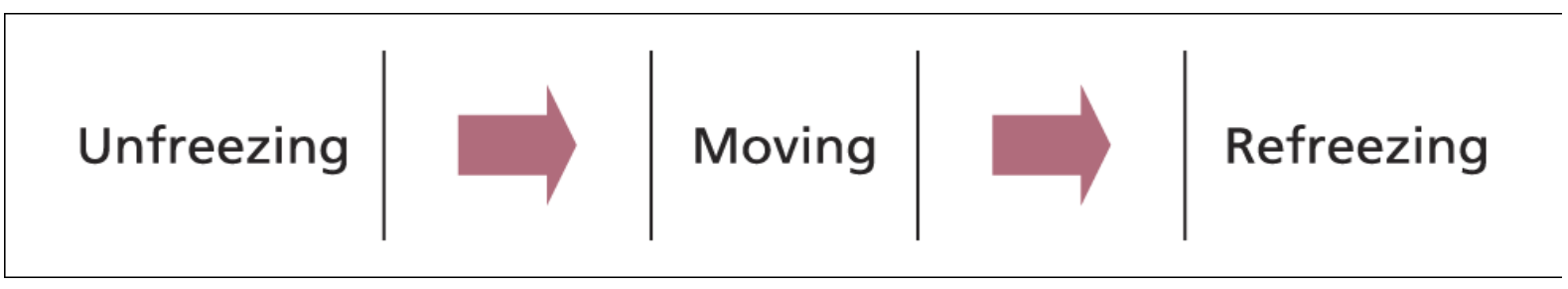

Figure 3: The Conventional View of Lewin's Three Step Model of Change ${ }^{1}$ (Adapted from Cumming and Worley, 2015: 23)

${ }^{1}$ It is now usual for the Freezing step to be referred to as Refreezing. 


\begin{tabular}{|l|l|l|l}
\hline $\begin{array}{l}\text { UNFREEZING } \\
\text { Core purpose: } \\
\text { Identifying and } \\
\begin{array}{l}\text { Destabilising Quasi- } \\
\text { Stationary } \\
\text { Equilibrium 1 }\end{array}\end{array}$ & $\begin{array}{c}\text { MOVING } \\
\text { Core purpose: } \\
\text { Changing } \\
\text { behaviour } \\
\text { through Action } \\
\text { Research }\end{array}$ \\
\hline
\end{tabular}

Group Dynamics, Democratic Participation and Choice

Figure 4: A Field Theory-Based View of Lewin's Three-Step Model 